\title{
Analisis Penggunaan Media Google Classroom terhadap Proses Belajar Mengajar pada Mahasiswa PGSD Universitas Quality Selama Masa Bencana Pandemi Covid-19
}

\author{
Nilam Sari ${ }^{1}$, Vera Dewi Kartini Ompusunggu ${ }^{2}$, Muhammad Daliani ${ }^{3}$ \\ Pendidikan Matematika, Universitas Quality \\ Email: nilamsarie@gmail.com ${ }^{1}$, nasranidua_ompusunggu@yahoo.com ${ }^{2}$, \\ mddaniboys@gmail.com ${ }^{3}$
}

\begin{abstract}
ABSTRAK: Perkembangan teknologi yang sangat canggih pada jaringan komputer yang menyediakan layanan informasi secara luas merupakan kemajuan dalam bidang teknologi komunikasi yaitu internet (international networking) memiliki manfaat yang sangat besar. Pencegahan musibah Covid 19 ini berdampak pada masyarakat melaksanakan Lockdown. Hal ini didasarkan pada Surat Edaran dari Menteri Pendidikan dan Kebudayaan Nomor: 36962/MPK.A/HK/2020 tertanggal 17 Maret 2020 tentang "Pembelajaran secara Daring dan Bekerja dari Rumah dalam rangka Pencegahan Penyebaran Corona Virus Disease (Covid19)". Dengan pembelajaran secara daring maka Univesitas Quality melaksanakan pembelajaran dengan meggunakan aplikasi dari internet yaitu Google Classroom. Penelitian yang digunakan merupakan jenis penelitian kualitatif dengan metode deskriptif. Teknik pengumpulan datanya diperoleh dari wawacara, dokumentasi dan kuiseoner (angket). Prosedur penelitiannya dilakukan secara online. Hal ini dikarenakan Lockdown. Hipotesis sementara yakni pembelajaran menggunakan Google Classroom pada Universitas Quality berjalan secara efektif selama musibah Covid 19. Hasil dari penelitian ini menunjukkan bahwa rata-rata dari semua kelas adalah 100,45 dan dari nilai keseluruhan diperoleh ratarata 3,35 berdasarkan table dengan kriteria cukup, sehingga pengguna google classroom menurut mahasiswa dirasa cukup membantu proses pembelajaran. Skor tertinggi kelas 2A21 126 dan skor terendah 80 sedangkan kelas 2 A22 skor tertinggi 121 dan skor terendah 84 , dengan rata-rata kelas 2A21 101,58 dan kelas 2A22 101,21.
\end{abstract}

Kata Kunci: Google Classroom, Keputusan KEMENDIKBUD, Musibah Covid-19

\begin{abstract}
The development of very sophisticated technology in computer networks that provides information services is an advancement in the field of communication technology, namely the internet (international networking) has enormous benefits. Prevention of the Covid 19 disaster has an impact on the community implementing a Lockdown. This is based on the Circular from the Minister of Education and Culture Number: 36962 / MPK.A / HK / 2020 dated 17 March 2020 concerning "Online Learning and Working from Home in the Context of Preventing the Spread of Corona Virus Disease (Covid-19)". With online learning, University Quality carries out learning using an application from the internet, namely Google Classroom. The research used is a type of qualitative research with descriptive methods. Data collection techniques were obtained from interviews, documentation and questionnaires (questionnaires). The research procedure is carried out online. This is due to Lockdown. The provisional hypothesis is that learning to use Google Classroom at Quality University ran effectively during the Covid 19 disaster. The results of this study indicate that the mean of all classes is 100.45 and from the overall score an average of 3.35 is obtained based on the table with sufficient criteria, so that the users of Google classroom according to students are deemed sufficient to help the learning process. The highest score was class 2A21 126 and the lowest score was 80, while class 2A22 had the highest score 121 and the lowest score was 84, with an average class 2A21 101.58 and class 2A22 101.21.
\end{abstract}

Keywords: Covid Disaster 19, Google Classroom, Ministry of Education and Culture decision. 


\section{PENDAHULUN}

Perkembangan

jaringan

komputer yang menyediakan layanan informasi secara luas merupakan kemajuan dalam bidang teknologi komunikasi. Internet (international networking) adalah sebuah jaringan global yang memungkinkan komputer melakukan komunikasi dengan dunia luar sebagai jalan utama informasi, sumber ilmu pengetahuan global dan mengandung arti kolaborasi serta kerjasama dalam komunitas yang berbeda (Ajuwon, 2003 dalam Kamaluddin dan Asrin, 2007). Sebagai sebuah sumber informasi yang hampir tidak terbatas, maka internet memenuhi kapasitas untuk dijadikan alternatif pada musibah yang terjadi pada tahun 2019 dan 2020.

Telah terjadi musibah diseluruh dunia pada awal 2020 yaitu musibah yang disebabkan oleh virus. Virus itu disebut dengan virus corona. Virus corona atau severe acute respiratory syndrome coronavirus 2 (SARS-CoV2) adalah virus yang menyerang sistem pernapasan. Penyakit karena infeksi virus ini disebut COVID-19. Virus corona bisa menyebabkan gangguan pada sistem pernapasan, pneumonia akut, sampai kematian. Virus ini bisa menyerang siapa saja, baik bayi, anak-anak, orang dewasa, lansia, ibu hamil, maupun ibu menyusui.

Infeksi virus ini disebut COVID-19 dan pertama kali ditemukan di kota Wuhan, Cina pada akhir desember 2019. Virus ini menular dengan cepat dan telah menyebar ke wilayah lain di Cina dan ke beberapa negara, termasuk Indonesia. Hal ini membuat beberapa negara di luar negeri menerapkan kebijakan untuk memberlakukan Lockdown dalam rangka mencegah penyebaran virus corona. Bahkan Nasir, dkk. (2020) mengatakan bahwa merebaknya pandemik Covid-19, secara nyata memunculkan efek domino pada semua sisi kehidupan. Seluruh umat manusia secara langsung atau tidak langsung ikut merasakannya.

Social distancing adalah situasi yang melarang warga untuk masuk ke suatu tempat karena kondisi darurat. Lockdown juga bisa berarti negara yang menutup perbatasannya, agar tidak ada orang yang masuk atau keluar dari negaranya. Sehingga dengan diberlakukan lockdown akibat musibah virus corona ini maka segala aktifitas diluar rumah ditiadakan termaksud aktifitas untuk berkerja, belajar dan lainlainnya. Ketiadaaan dalam aktifitas pembelajaran membuat segala bidang sektor (sektor perdagangan, sosial, termasuk juga pendidikan) memanfaatkan alat komunikasi kita yang sangat canggih yaitu internet.

Program- program pada aplikasi internet dimanfaatkan untuk tetap melakukan komunikasi akibat lockdown covid 19 tersebut. Bemacam-macam aplikasi digunakan untuk mendukung komunikasi salah satunya adalah whatsApp, BBM, twiter. Dan untuk bidang pendidikan banyak yang menggunakan aplikasi telegram dan google clasroom. Sedangkan untuk melakukan rapat dan meeting perusahaan juga menggunakan aplikasi zoom, hangouts dan masih banyak lainnya.

Hal ini didasarkan pada surat edaran dari Menteri Pendidikan dan Kebudayaan

Nomor: 36962/MPK.A/HK/2020 tertanggal 17 Maret 2020 tentang pembelajaran secara daring dan bekerja dari rumah dalam rangka pencegahan penyebaran corona virus disease (Covid-19). Sehingga dengan ini perguruan tinggi juga akan meliburkan mahasiswa. Tetapi jika diliburkan maka proses belajar mengajar tidak akan terlaksana. Dengan kecanggihan teknologi maka Universitas Quality melaksanakan proses belajar 
mengajar mengunakan aplikasi internet. Adapun aplikasi internet yang digunakan adalah Google Classroom. Google Classroom (Ruang Kelas Google) adalah suatu ruang pembelajaran campuran yang diperuntukkan terhadap setiap ruang lingkup pendidikan yang dimaksudkan untuk menemukan jalan keluar atas kesulitan dalam membuat, membagikan dan menggolong-golongkan setiap penugasan tanpa kertas.

Atas dasar hal tersebut maka dilaksanakanlah penelitian ini dengan judul "Analisis Penggunaan Aplikasi Google Classroom Terhadap Proses Belajar Mengajar Mahasiswa PGSD Universitas Quality Pada Masa Bencana Pandemi Covid 19".

Berdasarkan

permasalahan

diatas, maka tujuan penelitian ini adalah untuk mengetahui apakah dengan menggunakan aplikasi google clasroom (pembelajaran menggunakan daring) berjalan dengan efektif pada masa bencana Covid 19.

Adapun yang menjadi sasaran pada penelitian ini adalah mahasiswa PGSD Universitas Quality yang melaksanakan pembelajaran menggunakan Google Clasroom.

Sampai saat ini, belum ada vaksin untuk mencegah infeksi virus corona atau COVID-19. Oleh sebab itu, cara pencegahan yang terbaik adalah dengan menghindari faktor-faktor yang bisa menyebabkan Anda terinfeksi virus ini, yaitu:

1. Terapkan physical distancing, yaitu menjaga jarak minimal 1 meter dari orang lain, dan jangan dulu ke luar rumah kecuali ada keperluan mendesak.

2. Gunakan masker saat beraktivitas di tempat umum atau keramaian.

3. Rutin mencuci tangan dengan air dan sabun atau hand sanitizer yang mengandung alkohol minimal $60 \%$ setelah beraktivitas di luar rumah atau di tempat umum.

4. Tingkatkan daya tahan tubuh dengan pola hidup sehat.

5. Jangan menyentuh mata, mulut, dan hidung sebelum mencuci tangan.

6. Hindari kontak dengan penderita atau orang yang dicurigai menderita COVID-19.

7. Tutup mulut dan hidung dengan tisu saat batuk atau bersin, kemudian buang tisu ke tempat sampah.

8. Hindari berdekatan dengan orang yang sedang sakit demam, batuk, atau pilek.

9. Jaga kebersihan benda yang sering disentuh dan kebersihan lingkungan, termasuk kebersihan rumah.

Untuk orang yang diduga terkena COVID-19 atau termasuk kategori ODP (orang dalam pemantauan) maupun PDP (pasien dalam pengawasan), ada beberapa langkah yang bisa dilakukan agar virus corona tidak menular ke orang lain, yaitu:

1. Jangan keluar rumah (lockdown), kecuali untuk mendapatkan pengobatan.

2. Bila ingin ke rumah sakit saat gejala bertambah berat, sebaiknya hubungi dulu pihak rumah sakit untuk menjemput.

3. Lakukan isolasi mandiri dengan cara tinggal terpisah dari orang lain untuk sementara waktu. Bila tidak memungkinkan, gunakan kamar tidur dan kamar mandi yang berbeda dengan yang digunakan orang lain.

4. Larang dan cegah orang lain untuk mengunjungi atau menjenguk anda sampai Anda benar-benar sembuh.

5. Sebisa mungkin jangan melakukan pertemuan dengan orang yang sedang sedang sakit.

6. Hindari berbagi penggunaan alat makan dan minum, alat mandi, serta 
perlengkapan tidur dengan orang lain.

7. Pakai masker dan sarung tangan bila sedang berada di tempat umum atau sedang bersama orang lain.

Direktur Jenderal Pendidikan Tinggi Kemendikbud mengeluarkan surat edaran tentang masa belajar dan penyelenggaraan program pendidikan selama darurat virus corona. Hal ini didasarkan pada Surat Edaran dari Menteri Pendidikan dan Kebudayaan Nomor: $\quad 36962 / M P K . A / H K / 2020$ tertanggal 17 Maret 2020 tentang Pembelajaran secara Daring dan Bekerja dari Rumah dalam rangka Pencegahan Penyebaran Corona Virus Disease (Covid19).

Terkait Surat Edaran Kemendikbud, Dirjen Dikti merangkum dan menyampaikan 5 ketentuan yakni:

1. Masa belajar paling lama bagi mahasiswa yang seharusnya berakhir pada semester genap 2019/2020, dapat diperpanjang 1 semester, dan pengaturannya diserahkan kepada Pimpinan Perguruan Tinggi sesuai dengan kondisi dan situasi setempat.

2. Praktikum laboratorium dan praktek lapangan dapat dijadwal ulang sesuai dengan status dan kondisi di daerah.

3. Penelitian tugas akhir selama masa darurat ini agar diatur baik metode maupun jadwalnya, disesuaikan dengan status dan kondisi setempat.

4. Periode penyelenggaraan kegiatan pembelajaran semester genap 2019/2020 pada seluruh jenjang program pendidikan agar dapat disesuaikan dengan kebutuhan masing-masing perguruan tinggi sehingga seluruh kegiatan akademik dapat terlaksana dengan baik.

5. Persiapan pelaksanaan langkahlangkah sebagaimana disampaikan dalam angka 1 sampai 4 di atas agar terlebih dahulu dikoordinasikan dengan Lembaga Layanan Pendidikan Tinggi setempat.

Pemerintah melalui Kemendikbud menyebut Google Classroom sebagai salah satu platform pembelajaran daring terkait himbauan belajar dari rumah demi mencegah pandemi virus corona COVID-19 di Indonesia. "Beberapa pihak yang fokus mengembangkan sistem pendidikan secara daring antara lain Google Indonesia, Kelas Pintar, Microsoft, Quipper, Ruang guru, Sekolahmu, dan Zenius," pernyataan Kemendikbud pada 16 Maret 2020 lalu.

Google Classroom adalah bagian dari G Suite for Education yang juga hadir dalam versi aplikasi seluler. Untuk menggunakannya, pengajar dan murid wajib memiliki akun Google agar saling terhubung. Selain itu, lantaran bagian dari G Suite, Google Classroom terikat bersama Drive, Calender, Form, Jamboard, Hangouts Meet, Docs, Sheets, Slide, termasuk Gmail. Artinya, layananlayanan itu dapat dimanfaatkan dalam proses pembelajaran.

Google Classroom memungkinkan kegiatan belajar mengajar menjadi lebih produktif dan bermakna dengan menyederhanakan tugas, meningkatkan kolaborasi, dan membina komunikasi. Pengajar dapat membuat kelas, memberikan tugas, mengirim masukan, dan melihat semuanya di satu tempat. Sekolah dan lembaga nonprofit mendapatkan Google Classroom sebagai layanan inti $G$ Suite for Education dan $G$ Suite for Nonprofits secara gratis.

Google Classroom dapat disiapkan dengan mudah. Pengajar dapat menyiapkan kelas dan mengundang siswa serta asisten pengajar. Di halaman Tugas Kelas, mereka dapat berbagi informasi tugas, pertanyaan, dan materi. Dengan Google Classroom, pengajar dapat menghemat waktu dan kertas. Mereka dapat membuat kelas, 
memberikan tugas, berkomunikasi, dan melakukan pengelolaan, semuanya di satu tempat.

$$
\text { Google Classroom juga }
$$

menawarkan pengelolaan yang lebih baik. Siswa dapat melihat tugas di halaman Tugas, di aliran kelas, atau di kalender kelas. Semua materi kelas otomatis disimpan dalam folder Google Drive. Selain itu, Google Classroom memungkinkan alur komunikasi antara pengajar dengan murid atau antar murid lebih efektif. Pengajar dapat membuat tugas, mengirim pengumuman, dan memulai diskusi kelas secara langsung. Siswa dapat berbagi materi antara satu sama lain dan berinteraksi dalam aliran kelas atau melalui email. Pengajar juga dapat melihat dengan cepat siapa saja yang sudah dan belum menyelesaikan tugas, serta langsung memberikan nilai dan masukan real time. Yang tak kalah penting, Google Classroom terjangkau dan aman yang disediakan gratis untuk sekolah, lembaga nonprofit, dan perorangan serta tidak berisi iklan dan tidak pernah menggunakan konten pengguna atau data siswa untuk tujuan periklanan.

Google Classroom dapat diakses menggunakan internet di komputer dengan browser apa pun, seperti Chrome, Firefox, Internet Explorer, termasuk Safari. Secara umum, Google Classroom mendukung rilis browser utama secara berkelanjutan. Dengan kata lain, tidak perlu instalasi lantaran Google Classroom berbasis website. Akan tetapi, instalasi diperlukan bila mengakses Google Classroom melalui perangkat bergerak, lantaran juga tersedia untuk perangkat seluler berbasis Android dan Apple.

\section{METODE PENELITIAN}

Populasi yang dimaksud pada penelitian ini adalah Mahasiswa PGSD
Universitas Quality yang sedang melaksanakan proses pembelajaran menggunakan Google Classroom. Teknik pengambilan sampel yang digunakan peneliti dalam penelitian ini adalah teknik Simple Random Sampling. Dikatakan Simple (Sederhana) karena pengambilan anggota sampel dari populasi dilakukan secara acak tanpa memperhatikan rata-rata yang ada dalam populasi itu.

Penelitian ini merupakan jenis penelitian kualitatif dengan metode deskriptif. Penelitian deskriptif merupakan metode penelitian yang berusaha menggambarkan dan menginterprestasi objek sesuai dengan apa adanya. Teknik pengumpulan datanya diperoleh dari wawacara, dokumentasi dan kuiseoner (angket).

Prosedur penelitiannya dilakukan secara online. Hal ini dikarenakan Lockdown (menetap dirumah) sehingga wawancara dilakukan dengan video call dan untuk pemberian kuesioner juga dikirim dan didata melalui email.

\section{Teknik Analisis Data}

1. Melakukan konversi skorsing data dari kuesioner penilaian keefektifan penggunaan proses pembelajaran menggunakan Google Classroom terhadap mahasiswa. Agar bisa menganalisis data lebih lanjut, setiap jawaban dari kuesioner ini dikonversi skorsing kedalam bentuk numerik. Adapun skor yang diberikan pada setiap pernyataan, untuk pernyataan positif:

Skor 5 apabila responden menjawab Sangat setuju

Skor 4 apabila responden menjawab Setuju

Skor 3 apabila responden menjawab kurang setuju

Skor 2 apabila responden menjawab tidak setuju 
Skor 1 responden menjawab Sangat tidak setuju

Selanjutnya menghitung frekuensi setiap kategori jawaban dalam masing-masing variabel. Skor yang didapat kemudian dihitung dan memasukannya kedalam rumus deskriptif persentase.

Untuk memperoleh data skala kemandirian belajar yang diberikan sebelum dan sesudah pembelajaran menggunakan Google Classroom. Untuk melihat peningkatan ( $\mathrm{N}$-gain) dengan rumus:

$$
D p=\frac{n}{N} \times 100 \%
$$

Keterangan:

$D p=$ Skor yang diharapkan

$\mathrm{N}=$ Jumlah skor maksimal

$n=$ Jumlah skor yang diperoleh

Selanjutnya dari hasil analisis deskriptif kemudian dibuat keputusan, apakah penggunaan proses pembelajaran menggunakan Google Classroom sangat tinggi, tinggi, sedang, rendah atau sangat rendah.

$\begin{array}{ccr} & \text { Analisis data menggunakan } \\ \text { teknik deskriptif } & \text { kualitatif }\end{array}$ memanfaatkan persentase hanya merupakan langkah awal saja dari keseluruhan proses analisis. Analisis kualitatif tentu harus dinyatakan kedalam sebuah predikat yang menunjuk pada pernyataan keadaan, ukuran kualitas. Berdasarkan hal tersebut, maka hasil perhitungan berupa persentase tersebut diubah menjadi sebuah predikat, antara lain: $80,1 \%-100,0 \%=$ Sangat tinggi $60,1 \%-80,0 \%=$ Tinggi

$40,1 \%-60,0 \%=$ Sedang

$20,1 \%-40,0 \%=$ Rendah

$0,0 \%-20,0 \%=$ Sangat rendah
2. Hasil wawancara dengan mahasiswa dianalisis secara deskriptif.

3. Membuat kesimpulan dari hasil penelitian secara deskriptif terhadap penggunaan proses pembelajaran menggunakan Google Classroom apakah efektif, efisien serta dapat dipahami.

\section{HASIL PENELITIAN DAN PEMBAHASAN}

\section{Hasil Penelitian}

Penelitian ini dilaksanakan pada

27 Maret sampai dengan 09 Mei 2020, di kelas 2A21 dengan jumlah mahasiswa 40 orang dan $2 A 22$ dengan jumlah mahasiswa 36 orang Pendidikan Guru Sekolah Dasar Universitas Quality Tahun Ajaran 2019/2020, pada semester genap. Jenis penelitian ini adalah penelitian kualitatif, yaitu peneliti hanya ingin mengetahui bagaimana gambaran kemampuan mahasiswa menggunakan media google classroom terhadap proses belajar mengajar pada mahasiswa PGSD Universitas Quality selama masa bencana pandemic covid 19.

Tabel 1 Klasifikasi Penilaian Angket Siswa

\begin{tabular}{|c|c|}
\hline Interval Skor & Kriteria \\
\hline $\bar{x}>4,2$ & Sangat Baik \\
\hline $3,4<\bar{x} \leq 4,2$ & Baik \\
\hline $2,6<\bar{x} \leq 3,4$ & Cukup \\
\hline $1,8<\bar{x} \leq 2,6$ & Kurang Baik \\
\hline \hline $\bar{x} \leq 1,8$ & Tidak Baik \\
\hline
\end{tabular}

Tabel di atas menunjukkan bahwa skor tertinggi kelas 2A21 adalah 126 dan skor terendahnya adalah 80 sedangkan skor tertinggi kelas $2 \mathrm{~A} 22$ adalah 121 dan skor terendahnya adalah 84 . 


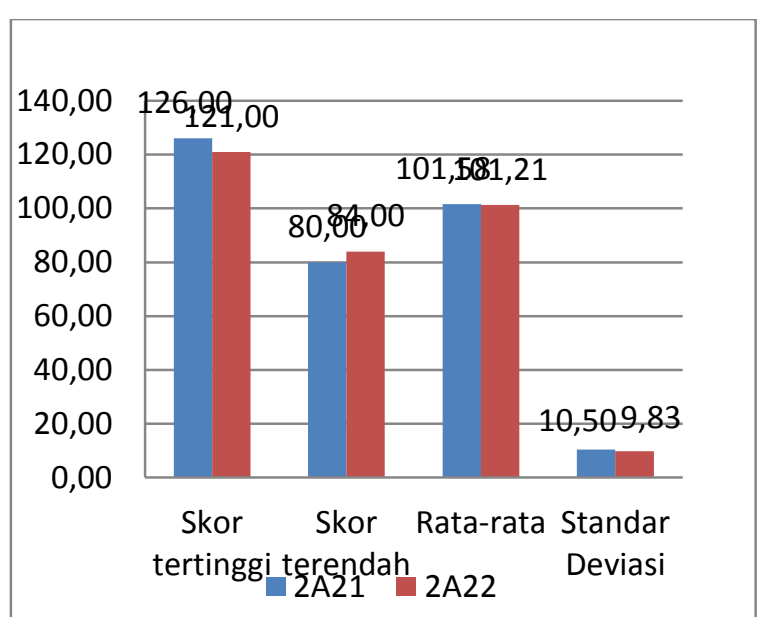

Chart 1 Data Perolehan Skor Masingmasing Kelas

Dari hasil data diketahui bahwa diterapkannya metode pembelajaran berbasis daring yaitu dengan penggunaan aplikasi google classroom cukup efektif untuk melengkapi implementasi dari pendekatan pembelajaran. Tahapan implementasi ini telah di sesuaikan dengan pendekatan pembelajaran yang digunakan selama ini, yaitu pendekatan kontekstual. Karena dalam memahami suatu materi pembelajaran harus mengetahui konteks dari inti setiap materi yang dipelajari sehingga materi yang di sampaikan dapat diterima oleh mahasiswa. Langkah pertama, membuat materi bahan ajar yang telah disesuaikan secara jelas dan dapat dipahami oleh mahasiswa, sehingga mahasiswa dapat belajar dengan mudah. Kemudian mengunggah materi tersebut ke dalam aplikasi google classroom. Materi tersebut tentang bacaan pembelajaran matematika dalam bentuk word ataupun pdf dan video tentang pembelajaran matematika sebagai referensi mahasiswa untuk belajar. Di aplikasi google classroom juga disediakan kolom komentar yang bertujuan untuk membuka ruang diskusi antara dosen dan mahasiswa. Sehingga mahasiswa dapat bertanya dengan mudah tentang materi yang dianggap sulit. Selanjutnya untuk proses pembelajaran di kelas disesuaikan dengan pendekatan kontekstual melalui aplikasi google classroom.

Kegiatan pembelajaran tersebut cukup efektif, karena berbagai macam referensi untuk belajar sudah diunggah ke aplikasi google classroom, sehingga mahasiswa dapat belajar dengan mudah. Selain itu mahasiswa juga merasa senang dan nyaman dengan adanya kemudahan mengakses materi pembelajaran.

Secara keseluruhan setelah diterapkannya pembelajaran matematika berbasis daring yaitu dengan penggunaan aplikasi google classroom dapat meningkatkan hasil belajar mahasiswa. Peningkatan di setiap siklus dapat dilihat berdasarkan nilai hasil belajar dengan Kriteria Ketuntasan Minimal (>75).

Berdasarkan hasil yang telah dicapai dalam penelitian yang telah dilakukan peneliti, berarti peneliti memperkuat pendapat para ahli. Penggunaan aplikasi Google Classroom dapat meningkatkan hasil belajar matematika pada mahasiswa kelas 2A21 dan 2A22 PGSD Universitas Quality. Dan kegiatan pembelajaran yang dapat meningkatkan keaktifan belajar juga berpengaruh terhadap hasil belajar siswa

\section{SIMPULAN}

Berdasarkan hasil penelitian maka dapat disimpulkan bahwa pembelajaran daring dengan penggunaan aplikasi google classroom sangat membantu proses pembelajaran. Sehingga dapat berpengaruh terhadap peningkatan hasil belajar siswa. Maka ditarik kesimpulan bahwa penggunaan media dengan menggunakan aplikasi 
Google Classroom dapat meningkatkan hasil belajar siswa kelas 2A21 dan kelas $2 A 22$ PGSD Universitas Quality.

\section{UCAPAN TERIMA KASIH}

Artikel ini tersusun atas kerjasama beberapa dosen dari Universitas Quality. Kami menyadari jika artikel ini dibuat atas partisipasi banyak pihak, untuk itu penulis mengucapkan banyak terima kasih kepada semua orang yang telah ikut berkontribusi. Ucapan terima kasih juga peneliti berikan kepada editor Journal of Education and Teaching (JET), Fakultas keguruan dan ilmu pendidikan, Universitas muhammadiyah kendari yang siap menyediakan media, dan telah memberikan saran, masukan, dan pelayanan untuk kesempurnaan artikel ini

\section{DAFTAR PUSTAKA}

Albetus Adit. (2020). 12 Aplikasi Pembelajaran Daring Kerjasama Kemendikbud, Gratis! [https://edukasi.kompas.com/read 2020/03/22/123204571/12aplikasi-pembelajaran-daringkerjasama-kemendikbudgratis?page=all]. (diakses Kompas.com-22/03/2020, 12:32 WIB).

Arif Mari Aditia. (2017). Pengaruh Penggunaan Internet Sebagai Media Belajar Terhadap Prestasi Belajar Mahasiswa Jurusan Administrasi Niaga Politeknik Negeri Jakarta. Jurnal Epigram, Vol.14 No.1.

Daryanto. (2016). Memahami Kerja Internet. Bandung : Yrama Widya.

Darma. (2015). Buku Pintar Menguasai Internet. Jakarta : Mediakita.

Ibnu Azis. (2020). Mengenal Google Classroom: Fungsi dan Cara Menggunakannya. [https://tirto.id/mengenal-googleclassroom-fungsi-dan-caramenggunakannya-eG7S. (diakses 23 Maret 2020)

Iftakhar Shampa. (2016). Google Classroom: What Works and How? Journal of Education and Social Sciences, Vol. 3, (Feb)

Merry Dame Cristy Pane. (2020). Virus Corona (COVID-19). [https://www.alodokter.com/viruscorona] (diakses 9 April 2020).

Nasir, Ishaq Bagea, Sumarni, Besse Herlina, Apriani Safitri. (2020). Memaksimalkan Fitur "Breaking Rooms" Zoom Meeting pada Pendidikan Anak Usia Dini di Masa Pandemi Covid-19. Obsesi : Jurnal Pendidikan Anak Usia Din, Volume 5 Issue 1 Pages 611-624.

Rohman, Moch, Fatkhoer. (2020). Google Classroom: jadikan kelas digital di genggaman anda. Bojonegoro: Pustaka intermedia.

Sugiono. (2016). Metode Penelitian Kuantitatif, Kualitatif, dan R\&D. Bandung : Alfabeta.

Sukardi. (2013). Metodologi Penelitian Pendidikan. Jakarta: Bumi Aksara.

Wikipedia. (2017) Google Classroom.https://en.wikipedia.or g/wiki/Google Classroom diakses pada tanggal 1 Mei 2018.

Yantina Debora. (2020). SE Dikti: Masa Belajar Diperpanjang 1 Sementer Akibat Corona. [https://tirto.id/sedikti-masa-belajar-diperpanjang-1sementer-akibat-corona-eKqH . Update Corona 12 April: 4.241 Positif, 373 Meninggal, 359 Sembuh] (diakses pada tanggal 4 April 2020). 